\title{
STUDENT PERCEPTIONS OF ECUADORIAN VIRTUAL PLATFORMS DURING THE COVID-19 PANDEMIC
}

PROBLEMS

OF EDUCATION

IN THE $21^{\text {st }}$ CENTURY

Vol. 79, No. 2, 2021

\author{
Magda Francisca Cejas Martínez \\ National University of the Chimborazo UNACH and University of \\ the Armed Forces ESPE, Ecuador \\ E-mail: magda.cejas@unach.edu.ec \\ Mercedes Navarro Cejas \\ Technical University of Manabí UTE, Ecuador \\ E-mail: mechyn4@gmail.com \\ Gina Silvana Venegas Alvarez \\ Cotopaxi Technical University UTC, Ecuador \\ Email: gina.venegas@utc.edu.ec \\ Carlos Enrique Proaño Rodríguez \\ University of the ESPE Armed Forces, Ecuador \\ Email: ceproanio@espe.edu.ec \\ Derling Jose Mendoza Velazco \\ National University of Education UNAE \& UTE University, Ecuador \\ E-mail: derling969@gmail.com
}

\begin{abstract}
In February 2020 Ecuador declared a health emergency due to the Covid-19 pandemic. On-site classes were suspended. The Ecuadorian university population does not adapt to virtual educational platforms. The objective of the study was to analyse student perception of Ecuadorian educational platforms in higher education during the COVID-19 pandemic. The study was quantitative. The sample was non-probabilistic participatory, consisting of students from different universities in the Province of Chimborazo. For data collection, a questionnaire with four study variables was applied. The results were analysed with $T$ student and MANOVA. There is a positive perception of students using the educational platforms. There were significant statistical differences according to gender variables, contrary to the levels of study and location, there is a greater sympathetic affection of students when receiving virtual classes by female teachers. It can be concluded that the Covid-19 pandemic accelerated the adoption of online learning by higher education institutions.

Keywords: Covid-19, virtual education, higher education, Ecuador, education platform, virtual education, Ecuador
\end{abstract}

\section{Introduction}

The Republic of Ecuador declares a health emergency due to the spread of the disease COVID-19. Prevention and control measures were taken to restrict meetings and mass events. Similarly, the application of technological platforms for virtual education and telemedicine 
Magda Francisca CEJAS MARTÍNEZ, Mercedes NAVARRO CEJAS, Gina Silvana VENEGAS ALVAREZ, Carlos Enrique PROAÑO RODRÍGUEZ, Derling Jose MENDOZA VELAZCO. Student perceptions of Ecuadorian virtual platforms during the Covid-19 pandemic

PROBLEMS

OF EDUCATION IN THE $21^{\text {st }}$ CENTURY Vol. 79, No. 2, 2021

242

(Primicias, 2020). Ecuador was paralysed by the outbreak of the coronavirus, which caused schools and universities to adjust to online teaching. The higher education system has begun an unprecedented experiment in online learning. The COVID-19 epidemic has not only seriously endangered the health of individuals but has profoundly changed the way of life and values of humanity. It has also placed humanity in a living environment of high risk and uncertainty.

König et al., (2020) emphasised that virtual education has become the centre of our current teaching model, but this situation continues without time certain. The difficult parts of the large-scale transition to online learning are not mentioned. Eickelmann and Gerick, (2020), consider that virtual class schedules must be readjusted to easily prioritize teaching online content. Universities need to consider student assignments. Especially when students are in different areas, economic status, lack of technological resources and coordination of work becomes very difficult to organize distantly. Grading criteria may also change, the weight of small weekly homework assignments will increase, and the weight of large final assessments will decrease. Many Ecuadorian universities faced difficulties in conducting online exams.

\section{Coronavirus SARS-CoV-2}

Coronavirus is a large family of viruses that can cause illnesses such as the common cold and even severe acute respiratory syndrome (SARS) and Middle East respiratory syndrome (MERS). China recently broke out with a disease that has spread to the world, namely COVID-19. The main cause has been confirmed to be a new type of virus called 2019 Novel Coronavirus (2019-CoV) (Hayat et al., 2020). Little is currently known about the new virus. Major public health organizations, including the World Health Organization (WHO) and the US Centre for Disease Control and Prevention (CDC), are closely monitoring the development of the virus and posting the latest information through their respective websites. These organizations also issued some recommendations on how to prevent and treat illnesses caused by the virus.

Under the new 2019 coronavirus pneumonia epidemic (COVID-19), as some higher education institutions prepare to reopen or maintain courses, many must face the challenge of ensuring the safety of students, faculty, staff, and volunteers. Health monitoring and preventive standards must provide precautions on how to help protect students and employees (such as teachers, staff, and administrative personnel) and thus slow the spread of COVID-19. According to Sintema (2020), extracurricular and non-formal online education is being developed globally as a preventive measure. For others, however, online education has become a formal necessity in recent weeks. The current public health emergency is pushing online education to take the lead. For years, discussions on online education were abundant, in this sense, face-to-face interaction is still the main form of education, while online education plays an assistance role.

\section{Distance Learning}

While the world is working hard to cope with the impact of COVID-19, the demand for online education, online research, distance learning and online leisure activities puts educational institutions around the world in a unique service position. Over the years, universities have accumulated a wealth of online experience. The pandemic of disease has forced universities to shift from general face-to-face learning to online learning (Byrnes, et al., 2020). According to Zhou, et al., (2020), among the recommendations for the prevention of new coronavirus infection (COVID-19), are regulations for higher education institutions to establish virtual classes through PE. Laboratory classes become digital, webinars, lectures, practical exercises, in a full-time format and in an electronic information and education environment. Personal accounts of students and teachers, email. Cloud recordings and other educational technologies that allow indirect (distance) interaction of students and teachers. 
Magda Francisca CEJAS MARTÍNEZ, Mercedes NAVARRO CEJAS, Gina Silvana VENEGAS ALVAREZ, Carlos Enrique PROAÑO RODRÍGUEZ, Derling Jose MENDOZA VELAZCO. Student perceptions of Ecuadorian virtual platforms during the Covid-19 pandemic

To clarify the aspects of the distance education regime, Al awamrah (2015) stated that distance learning cannot be organized without a computer in the students' home and the teachers' home. Computer technology must be available, mainly in residences of socially vulnerable students. For high quality organization of distance learning and comfortable communication one should not leave home. High speed internet is needed at home. Distance activities offer interaction to learners, enabling training, analysis, discussion, debate, and decision-making. Underlying distance learning is the technology of the educational process. This is mainly done using information and telecommunication technologies in an indirect (distance) or not fully mediated way through learner and teacher interaction. It provides interactivity to remote participants through open access channels (Internet, etc.) (Akande, et al., 2020).

For AL-Salahat, (2016), distance learning are lectures, seminars, colloquiums, presentations with reports. Teachers choose the platforms of class organization that are optimal for their course. These include conference calls, online broadcasts, group chats on social networks and instant messaging, online tests, etc. At the technological level, the most widely applied educational systems are Google Classroom, Chamilo LMS, Microsoft Teams, Moodle, NEO LMS, Schoology, Edmodo and Blackboard Open LMS (Alfredsson et al., 2020). Within virtual platforms there should be scientific social networks to foster personal educational and disseminate scientific knowledge (Sun et al., 2020)

Excessive internet use by university students can alter hormone levels due to dependence on virtual networks (Wahab, 2020). For example, when EPs are applied, the hormone oxytocin, which is responsible for feelings of empathy, is released (Sindiani, et al., 2020). The disadvantage is that a person loses the ability of real communication, being used to online communication. When texting in EPs, the person does not follow the rules of grammar and punctuation. It is a general influence of different technologies. They use poor vocabulary, emotions are replaced by emoticons, all this negatively affects communication in the real world. But nowadays the Internet is positive and necessary for the university student's life (Dhawan, 2020).

\section{Research Problem}

The current educational process cannot be imagined without the use of Internet resources and connection technologies. The idea of distance learning and monitoring educational activities for students seems very promising. Distance teaching and learning is gaining special significance nowadays, with the development of the Internet. Students owning personal computers, the exchange of information between teachers and students is improving. All this contributes to the digitisation of the educational process. In the framework of the educational process, the most effective direction for the development of distance learning can be the establishment of educational platforms (EP) and virtual activities. But there is a serious drawback to work through these sites, it is their extreme unpopularity with students. The lack of preparation prevents to achieve remarkable results in the educational process, also in the evaluation process. It is important to note that a pandemic and its consequent quarantine present an educational challenge that must be considered. How to educate students when they are unable to attend university presents a difficulty, but also an opportunity.

\section{Research Aim and Research Questions}

As a problematic research situation, the following questions emerged:

- What is the reality of educational platforms in university education during the COVID-19 pandemic?

- Are there statistically significant differences in university distance education platforms during the COVID-19 pandemic according to the variables gender, specialization, theory/ practice, university stage and student location?
PROBLEMS

OF EDUCATION

IN THE $21^{\text {st }}$ CENTURY

Vol. 79, No. 2, 2021

243 
Magda Francisca CEJAS MARTÍNEZ, Mercedes NAVARRO CEJAS, Gina Silvana VENEGAS ALVAREZ, Carlos Enrique PROAÑO RODRÍGUEZ, Derling Jose MENDOZA VELAZCO. Student perceptions of Ecuadorian virtual platforms during the Covid-19 pandemic

PROBLEMS

OF EDUCATION IN THE $21^{\text {st }}$ CENTURY Vol. 79, No. 2, 2021 244

- What is the impact on academic performance before and after the COVID-19 pandemic when applying the virtual platforms of higher education students?

To answer these questions, the following study objectives were proposed:

- Research the reality of higher education educational platforms during the COVID-19 pandemic.

- To analyse whether there are statistically significant differences in the use of higher education educational platforms during the COVID-19 pandemic, from the variables, gender, specialization, theory/practice, stage, location of study and special needs in teaching.

- To describe student perception of virtual platforms in university education. To describe academic performance before and during the COVID-19 pandemic.

Highlight student perception of PE in distance education. To analyse academic performance before and during the COVID-19 pandemic. From a practical point of view, this research highlights variables that could affect the implementation of virtual education during the COVID-19 pandemic.

\section{Research Methodology}

\section{Research Design}

In order to achieve the objectives of the study, research was designed based on the quantitative method. The quantitative methods aim to obtain information that is presented in numerical terms (Boeren, 2018). It demonstrates the participant's behaviour and reaction to certain research activities. The main task of such studies is to obtain numerical data, the reaction of respondents to any event. Quantitative studies analyse the opinion of a sufficiently large number of people (large sample), and this can serve as an indicator of the objectivity and reliability of the data obtained. The research time was 2 months. The scope of the study was exploratory and descriptive. The exploratory scope was characterised by presenting information on a phenomenon, including the identification of the variables to be studied. Descriptive scoping is a methodological and technical procedure organised logically and objectively (Mellinger and Hanson, 2016). These scopes made it possible to obtain reliable data on the phenomenon and to describe its variables accurately.

\section{Population and Sample}

The research population consisted of the university students from the province of Chimborazo, Republic of Ecuador during the academic year B-2020. Chimborazo National University (UNACH) has 9842 students (UNACH, 2021). Chimborazo Polytechnic High School (ESPOCH) has 13000 students (ESPOCH, 2021). The Autonomous Regional University of the Andes (UNIANDES) has 700 students (UNIANDES, 2021). Non-statistical purposive sampling was used for sample selection. Non-statistical sampling is most useful for exploratory studies. Non-probability sampling is used where it is not possible to draw a random probability sample, due to time or cost considerations (Cornesse et al., 2020). In non-statistical purposive sampling, researchers choose only those deemed suitable (Dănescu and Anca, 2012). Under this criterion, the students chosen were in their final year of university studies. The senior students are more committed, knowledgeable, and experienced.

In the study there are people from different professions and age categories, with different work experience, educational level, all in the same city. In this situation for the present study, the sample allocation was relatively homogeneous in the object structure. This selection made it possible to alternatively assess and compare the characteristics of interest to the researchers. The presence or absence of connections between them was identified (Zhang et al., 2020). The 
Magda Francisca CEJAS MARTÍNEZ, Mercedes NAVARRO CEJAS, Gina Silvana VENEGAS ALVAREZ, Carlos Enrique PROAÑO RODRÍGUEZ, Derling Jose MENDOZA VELAZCO. Student perceptions of Ecuadorian virtual platforms during the Covid-19 pandemic

researchers designed and sent a participatory email invitation letter to students at the above universities. For considerations of time, cost and preventive health measures of non-crowding and distancing of people (Covid-19). Students who chose to participate were selected according to the criteria of study variable, gender, major, place of study and educational level (see Table 1).

\section{Table 1}

Distribution of the Study Sample According to the Variables

\begin{tabular}{lccc}
\hline Variables & Category & Frequency & Percentage \\
\hline \multirow{2}{*}{ A. Gender } & Male & 249 & 49.8 \\
\hline \multirow{nyyy}{*}{ B. Specialization } & Female & 251 & 50.2 \\
\hline \multirow{nyyy}{*}{ C. Student location } & Theoretical & 302 & 60.4 \\
\hline \multirow{nyyy}{*}{ D. Educational level } & Practical & 198 & 39.6 \\
\cline { 2 - 4 } & Headquarters & 111 & 22.2 \\
\hline
\end{tabular}

Instrument

The current study sought to measure the reality of digital distance learning platforms during the COVID-19 pandemic from the point of view of university students. This reality could be described through the attitudes or attitudinal levels of the students. For this purpose, a Likert questionnaire was designed as a data collection instrument. 5-point Likert scale was used. The first option Always (S) with a value greater than 5. Then the option Almost Always (CS) with a value of 4 . The middle option Sometimes (AV) with a value of 3 . Then the option Never (N) with the lowest value of only 1 point (Pari et al., 2020).

\section{Reliability of the Instrument}

The reliability of the internal consistency between the questions was determined by Cronbach's Coefficient Alpha. To test the reliability, a diagnostic pilot test was applied to 10 students. Statistical analyses were performed in software package SPSS.25. The questionnaire comprised four variables (gender, university educational specialization, location of the student, educational level). The reliability level of the 21 items was .892. The Cronbach's statistical results, being in the range of .800 and .899 , are highly reliable. This assures researchers to use the study tool and trust the results of its application (Mendoza et al., 2019).

\section{Data Analysis}

For data analysis, descriptive statistics were applied using four study variables. The first was the gender variable (VAR.A). The second variable was university educational specialization (VAR.B). The third variable referred to the location of the student (VAR.C). The fourth variable was the educational level (VAR.D). Student's $t$ test and the study of standard deviation were developed. The study allows to analyse the mean between each variable. Also, analyse the distribution of the data from the mean. For the analysis of the data, it was considered that a low Standard Deviation (SD) indicates that the data points tend to be close to the mean of the data set. A high SD indicates that the data points are distributed over a wider range of values (Jurková et al., 2020).
PROBLEMS

OF EDUCATION

IN THE $21^{\text {st }}$ CENTURY

Vol. 79, No. 2, 2021 
Magda Francisca CEJAS MARTÍNEZ, Mercedes NAVARRO CEJAS, Gina Silvana VENEGAS ALVAREZ, Carlos Enrique PROAÑO RODRÍGUEZ, Derling Jose MENDOZA VELAZCO. Student perceptions of Ecuadorian virtual platforms during the Covid-19 pandemic

PROBLEMS

OF EDUCATION

IN THE $21^{\text {st }}$ CENTURY Vol. 79 , No. 2, 2021

As a second component of statistical analysis, the MANOVA analysis of variance was run. The MANOVA consists of a single ANOVA with several independent variables. The test helps to answer many research questions, including the comparison of means of several variables. The MANOVA analysis of variance provides a way to make multiple comparisons of several population means (Zhao, et al., 2019). To perform the MANOVA test, comparisons were made of the variances between sample means, as well as the within-sample variance of each of the samples.

\section{Research Results}

To answer the first question: What is the reality of educational platforms in distance education during the COVID-19 pandemic from the point of view of university students? The statistical properties of the sample calculation provide descriptive answers about the reality of educational platforms with 5-points of the response options set out in the questionnaire (see Table 3).

Table 3

Descriptive Statistics

\begin{tabular}{lccc}
\hline Variable & Ranking & Mean Deviation & $S D$ \\
\hline VAR.B & 4 & 1.1280 & 0.33 \\
\hline VAR.C & 5 & 1.0730 & 0.37 \\
\hline VAR.D & 3 & 1.0720 & 0.25 \\
\hline
\end{tabular}

The table above shows the degree of benefiting from distance learning considering the Covid-19 pandemic. All expressions were high, although the challenge was great in the importance of using and benefiting from distance education. The results showed that the variable B, (questionnaire items B.1 and B.5) were ranked among the high levels with a ranking of 4 (almost always). Similarly, for variable C (questions, C.3 and C.4) they presented a ranking of 5 (always). It can be described that the reality of university educational platforms was always important. Important in terms of facilitating educational, economic and connectivity benefits. For the results of variable D (question D.4) a medium level classification was obtained, with a ranking of 3 (sometimes). This result considers that the university virtual platforms sometimes allow the establishment of effective groups to develop activities and homework according to the level of studies.

To answer the second question. The answer was provided using the t-test and one-way analysis of variances (ANOVA). For variable A (gender) the results are shown in Table 4.

Table 4

Statistical Differences in the Use of Educational Platforms With Respect to the Gender Variable

\begin{tabular}{|c|c|c|c|c|c|c|}
\hline Gender & Statistics themselves & $N$ & $t$ & $d f$ & $p$ & $S D$ \\
\hline Male & \multirow{2}{*}{ Statistical function } & 249 & \multirow{2}{*}{3.920} & \multirow{2}{*}{500} & \multirow{2}{*}{.0001} & 3.914 \\
\hline Female & & 251 & & & & 4.883 \\
\hline
\end{tabular}


Magda Francisca CEJAS MARTÍNEZ, Mercedes NAVARRO CEJAS, Gina Silvana VENEGAS ALVAREZ, Carlos Enrique PROAÑO RODRÍGUEZ, Derling Jose MENDOZA VELAZCO. Student perceptions of Ecuadorian virtual platforms during the Covid-19 pandemic

It is evident from Table 3, visualised by the standard deviation, that there are statistically significant differences in the use of educational platforms in distance education during the COVID-19 pandemic from the students' point of view. The results showed that students felt more sympathetic affection when they received videoconferences or virtual classes from female teachers, as opposed to male teachers. Regarding the variable of university training specialisation (Theory / Practice), the results are presented in Table 5.

\section{Table 5}

Statistical Differences between Theoretical and Practical Training Perceived by University Students with the Use of Educational Platforms

\begin{tabular}{llccccc}
\hline Specialization & $\begin{array}{l}\text { Statistics } \\
\text { themselves }\end{array}$ & $\boldsymbol{N}$ & $\boldsymbol{t}$ & $\boldsymbol{d f}$ & $\boldsymbol{p}$ & $\boldsymbol{S D}$ \\
\hline Theoretical & Statistical function & 302 & & & & 4.515 \\
\cline { 3 - 6 } & & 198 & .691 & 500 & .490 & 4.578 \\
\hline
\end{tabular}

In Table 5, there are no statistically significant differences regarding the use of educational platforms in distance education during the COVID-19 pandemic from the students' point of view according to the variable specialisation either theoretical or practical. The data indicate that all participants use educational platforms equally. For the study of the location variable, the results are presented in Table 6.

\section{Table 6}

Significant Statistical Differences in Student Location Variable when Using College Educational Platforms

\begin{tabular}{llccccc}
\hline Studio location & $\begin{array}{l}\text { Statistics } \\
\text { themselves }\end{array}$ & $\boldsymbol{N}$ & $\boldsymbol{t}$ & $\boldsymbol{d f}$ & $\boldsymbol{p}$ & $\boldsymbol{S D}$ \\
\hline Headquarters & Statistical function & 111 & \multirow{2}{*}{1.886} & 500 & .000 & 4.090 \\
\cline { 1 - 5 } Core & 389 & & & & 4.851 \\
\hline
\end{tabular}

It is evident from the table above that there are statistically significant differences with respect to the variable location of the students. Most of the students are in their homes or in cities distant from the main university campus (Province of Chimborazo) during the Covid-19 pandemic. From the point of view of the students, according to the variable of the academic headquarters, the use of distance learning educational platforms provides favourable benefits for current university education. For the educational level variable, the results are shown in Table 7.

\section{Table 7}

Significant Differences in the Variable Educational Level of College Students when Using Educational Platforms during the Covid-19 Pandemic

\begin{tabular}{|c|c|c|c|c|c|c|}
\hline Educational level & $\begin{array}{l}\text { Statistics } \\
\text { themselves }\end{array}$ & $N$ & $t$ & $d f$ & $p$ & $S D$ \\
\hline Undergraduate & \multirow{2}{*}{ Statistical function } & 410 & \multirow{2}{*}{.497} & \multirow{2}{*}{500} & \multirow{2}{*}{.628} & 4.624 \\
\hline postgraduate & & 90 & & & & 4.523 \\
\hline
\end{tabular}


Magda Francisca CEJAS MARTÍNEZ, Mercedes NAVARRO CEJAS, Gina Silvana VENEGAS ALVAREZ, Carlos Enrique PROAÑO RODRIGUEZ, Derling Jose MENDOZA VELAZCO. Student perceptions of Ecuadorian virtual platforms during the Covid-19 pandemic

PROBLEMS

OF EDUCATION IN THE $21^{\text {st }}$ CENTURY Vol. 79 , No. 2, 2021

Table 7 shows that there were no statistically significant differences according to the educational level variable when using university educational platforms during the Covid-19 pandemic. According to students at both undergraduate and postgraduate level, the use of virtual activities at the research level was effective. To analyse the variations descriptively, the statistical data from the ANOVA calculation are presented in Table 8.

Table 8

MANOVA Statistical Calculation

\begin{tabular}{|c|c|c|c|c|c|}
\hline \multicolumn{6}{|c|}{ Multiple Comparison } \\
\hline $\begin{array}{l}\text { Independent } \\
\text { variable }\end{array}$ & Mean Square & $S E$ & $p$ & Lower Bound & Upper Bound \\
\hline VAR.A & 13900 & 4.100 & 0.753 & 6.8002 & 20.3256 \\
\hline VAR.B & 13850 & 4.540 & 0.002 & -20.3256 & -68002 \\
\hline VAR.C & 13800 & 4.461 & 0.001 & 6.9700 & 20.4506 \\
\hline VAR.D & 14100 & 4.580 & 0.000 & 7.2220 & 21.4450 \\
\hline
\end{tabular}

Table 8 shows that the mean scores of the gender variable (VAR.A) were statistically significant when compared to the other three variables with $p=0.753$. The variables of specialisation (VAR.B), student location (VAR.C) and educational level (VAR.D) were not statistically significant $(p<.0005)$.

Question 3 states: What is the impact on the academic performance of university students before and after the COVID-19 pandemic when applying the virtual platforms? The statistical data are presented in table 9 .

\section{Table 9}

Differences between Average Scores in the Use of Educational Platforms in Distance Education and their Impact on Academic Achievement Before and After the COVID-19 Pandemic

\begin{tabular}{llccccc}
\hline $\begin{array}{l}\text { Academic } \\
\text { achievement }\end{array}$ & $\begin{array}{l}\text { Statistics } \\
\text { themselves }\end{array}$ & $\boldsymbol{N}$ & $\boldsymbol{t}$ & $\boldsymbol{d f}$ & $\mathbf{p}$ & $\mathrm{SD}$ \\
\hline Before COVID-19 & Statistical function & 500 & & & & 1.040 \\
\cline { 3 - 6 } & & 500 & & 500 & .000 & 1.149 \\
\hline After COVID-19 & & & & & \\
\hline
\end{tabular}

It is evident from Table 9 that there are statistically significant differences. On the scale of educational platforms in distance education during the Covid-19 pandemic from the point of view of university students. The formative specialisation variable items B.2, B.6 and B.7 gave the results "almost always facilitates academic performance through virtual activities", as well as "levels of comfort and satisfaction with the evaluative results obtained". The student location variable was developed through items C.2 and C.5. Item C.2 had the lowest average value with a score of 3 (Sometimes). In comparison to item C.5 with an average value of 4 (Almost always). This shows that students have a greater ease of learning in virtual education, compared to face-to-face mode. 
Magda Francisca CEJAS MARTÍNEZ, Mercedes NAVARRO CEJAS, Gina Silvana VENEGAS ALVAREZ, Carlos Enrique PROAÑO RODRÍGUEZ, Derling Jose MENDOZA VELAZCO. Student perceptions of Ecuadorian virtual platforms during the Covid-19 pandemic

Regarding the level of undergraduate and postgraduate studies, the students with item D.3 all of them stood out with a rank of 5 (Always). This demonstrates the usefulness of applying and owning videoconferences, activities and courses recorded on the platform. In the same way, for item D.5 the students reported that at research level, with average 5 (Always) to be able to develop in an easy and accessible way the research activities by means of the university virtual platform. This indicates that the Covid-19 pandemic has effectively contributed to increasing the virtual academic average.

\section{Discussion}

From the students' point of view the use of educational platforms during the COVID-19 pandemic is generally positive. However, statistical results showed that there are significant differences in the use of educational platforms in distance education during the COVID-19 pandemic with respect to gender affectivity (male/female) in favour of females. For Bullough (2015) male teachers in basic elementary and high school education are of low frequency compared to higher or university education. These differences permeate the educational mind and consciousness; hence students expect to receive educational activities from female teachers. In Ecuadorian culture as in other countries, gender differences, beliefs and educational preferences are found, in this order. Ahmad et al., (2019) state that similarities between male and female teachers were found to be important. For the present study, university students in the Province of Chimborazo showed more sympathetic affection when receiving classes or educational guidance from female professors.

For students, with respect to the reality of university educational platforms during the Corona COVID-19 pandemic, there are no statistically significant differences. The qualifying ranking of high reliability and accessibility to an educational platform is determined by Waller, et al., (2020). The researcher indicates that online education allows the teacher and students to set their own pace of learning. It also allows for the added flexibility of setting a timetable that suits everyone's schedule. Regarding the variable of training or educational specialisation, whether theoretical or practical, it was established that all students use remote educational platforms. Ashe \& Molina (2021) confirmed that the use of an online educational platform allows a better balance between work and studies, so there is no need to give up anything. Studying online promotes vital time management skills, making it easier to find a good balance between work and study. Having a common agenda between student and teacher can also encourage both parties to accept new responsibilities and have more autonomy.

Regarding the variable of the academic seat or student location, the result was in favour of the main location, i.e., home. There were statistically significant differences on the scale of educational platforms in distance education. The academic rate before and during the Covid-19 pandemic showed results in favour of the post-academic average evaluation. This indicates that the quarantine has indeed contributed to an increase in the academic rate. This is consistent with that confirmed by the study of Akande, et al., (2020) and Al awamrah, (2015). The authors state that studying online in a university environment is a challenge to the cost of equipment (hardware and software). Although it may be a one-time purchase to acquire hardware, the university does not provide budgetary funds to set up the technology at home.

Instructional design must integrate the use of technology, adjust the value of skills development, and optimise feedback opportunities across platforms. All this so that students can gain advanced skills development and improve content knowledge through virtual education (Olasile \& Soykan, 2020). In addition to the text-based tests and exams, students should also analyse and study virtually in creative ways. Assessments should provide answers based on the educational platform through applied didactic methods (Mirbabaie, et al., 2020 and Rapanta, et al., 2020).
PROBLEMS

OF EDUCATION

IN THE $21^{\text {st }}$ CENTURY

Vol. 79, No. 2, 2021 
Magda Francisca CEJAS MARTÍNEZ, Mercedes NAVARRO CEJAS, Gina Silvana VENEGAS ALVAREZ, Carlos Enrique PROAÑO RODRIGUEZ, Derling Jose MENDOZA VELAZCO. Student perceptions of Ecuadorian virtual platforms during the Covid-19 pandemic

PROBLEMS

OF EDUCATION IN THE $21^{\text {st }}$ CENTURY Vol. 79, No. 2, 2021

250

Finally, it is known that educational platforms are an important means to develop virtual classes. Students develop skills and metacognitions that allow them to learn autonomously and self-regulated. University EP facilitate communication. They establish a rapprochement between teaching staff and students. This two-way communication can be synchronous and asynchronous. But the results showed significant data in the research. The students perceive that the virtual EP are of temporary use by the Covid-19. Students feel affective preference for female teachers. The time factor is established. This factor establishes the balance between work and time. By having control of time, there is autonomy in virtual learning. It was shown that postgraduate students had better evaluative results. They had more time to carry out online research.

\section{Conclusions and Implications}

It can be concluded that university educational platforms are academic communities in which they establish various types of relationships (research, guidance, friendship, work, education, training, internships, etc.). EP allow their members to be in continuous communication and interaction based on a given educational dynamic. Their application in education brings new challenges for teachers and students to find in them a new way of teaching. They also break with traditional classroom-only teaching schemes. ICTs are a milestone in the ways of relating and interacting, providing innovative resources for accessing information and knowledge. However, the main challenges to overcome are access to these resources, mainly the Internet, literacy, training in the use of the Web, the management of learning-oriented communities and the selection of relevant technological resources.

Educational platforms break the traditional paradigms of education, allocating the necessary time to follow the contents. They also promote the appropriate use of interactive digital platforms. As mentioned above, the time factor helped to set the pace of study. In this way, the students perceived that the educational platforms are very flexible in their planning. At the evaluative level, the results before and during the Covid-19 pandemic were positive. Especially for postgraduate students. The coordination of time allowed a better distribution of class schedules. Flexibility in virtual education went hand in hand with convenience in learning. In the research, university students perceived greater sympathy with classes taught by female professors.

Online education also favoured autonomy to the individual needs and ability level of each student. Online classes are usually shorter than conventional classes. Most of the time, online learning platforms allow for a limited number of students at a time, which allows for more interaction and feedback between teacher and student. In addition, there is access to a wide range of material, such as videos, photos, and e-books. University lecturers can also integrate other formats, such as forums or discussions, to enhance their classes. This content is available at any time and from anywhere, offering a more dynamic and personalised education. Online education is spreading. The Covid-19 pandemic accelerated the adoption of online education by higher education institutions around the world.

\section{References}

Ahmad, A., Ziad, S., \& Heather, F. (2019). Teaching style differences between male and female science teachers in Qatari schools: possible impact on student achievement. EURASIA Journal of Mathematics, Science and Technology Education, 15(12), 1-16. https://doi.org/10.29333/ ejmste/109236

Akande, O., Badmus, T., Akindele, A., \& Arulogun, O. (2020). Dataset to support the adoption of social media and emerging technologies for continued student participation. Data in Brief, 25(31), 1-7. https://doi.org/10.1016/j.dib.2020.105926 
Magda Francisca CEJAS MARTÍNEZ, Mercedes NAVARRO CEJAS, Gina Silvana VENEGAS ALVAREZ, Carlos Enrique PROAÑO RODRÍGUEZ, Derling Jose MENDOZA VELAZCO. Student perceptions of Ecuadorian virtual platforms during the Covid-19 pandemic

Al awamrah, A. (2015). Attitudes towards e-learning at the faculty of education sciences- University of Jordan. Revista Europea de Ciencias Sociales, 47(1), 96-112.

Alfredsson, K., Kjellberg, A., \& Hemmingsson, H. (2020). Internet opportunities and risks for adolescents with intellectual disabilities: a comparative study of parents' perceptions. Scandinavian Journal of Occupational Therapy, 27(8), 601-613. https://doi.org/10.1080/11038128.2020.1770330

AL-Salahat, M. (2016). Using video modeling in teaching a simple meal preparation skill for Down syndrome students. Revista de Educación y Práctica, 7(9), 82-90. https://files.eric.ed.gov/fulltext/ EJ1095812.pdf

Ashe, S., \& Molina, R. (2021). Communication in online learning - how important is it? The Clearing House: A Journal of Educational Strategies, Issues and Ideas, 94(1), 15-30. https://doi.org/10.1080/00098655.2020.1835795

Autonomous Regional University of the Andes, UNIANDES. (2021). Universidad regional Autónoma de los Andes. to the height of your dreams. https://uniandes.edu.ec/ToTheHeightOfYourDreams/ quienes-somos/

Boeren, E. (2018). Methodological underdog: A review of quantitative research in key adult education journals. Adult Education Quarterly, 68(1), 63-79. https://doi.org/10.1177/0741713617739347

Bullough, R. (2015). Differences? similarities? male teacher, female teacher: An instrumental case study of teaching in a head start classroom. Teaching and Teacher Education, 47, 13-21. https://doi.org/10.1016/j.tate.2014.12.001

Byrnes, K., Kiely, P., Dunne, C., McDermott, K., \& Coffey, J. (2020). Communication, collaboration and contagion: Virtualization of anatomy during COVID-19. Clinical anatomy, 34(1), 82-89. https://dx.doi.org/10.1002\%2Fca.23649

Chimborazo National University, UNACH. (2021). Figures and research. https://www.unach.edu.ec/ unach-en-cifras/

Chimborazo Polytechnic High School, ESPOCH. (2021). Transparency 2020. https://www.espoch.edu. ec/index.php/2020-t.html

Cornesse, C., Blom, A., Dutwin, D., Krosnick, J., De Leeuw, E., Legleye, S., Pasek, J., Pennay, D., Phillips, B., Sakshaug, J., Struminskaya, B., \& Wenz, A. (2020). Review of conceptual approaches and empirical evidence on probability and nonprobability sample survey research. Journal of Survey Statistics and Methodology, 8(1), 4-36, https://doi.org/10.1093/jssam/smz041

Dănescu, T., \& Anca, C., (2012). Opportunity and necessity in audit sampling non-statistical sampling method. Procedia Economics and Finance, 3, 1128-1133. https://doi.org/10.1016/S22125671(12)00285-7

Dhawan, S. (2020). Online learning: A panacea in times of COVID-19 crisis. Revista de sistemas de tecnología educativa, 49(1), 5-22. https://doi.org/10.1177/0047239520934018

Eickelmann, B., \& Gerick, J. (2020). Learning with digital media. Objectives in times of Corona and under special consideration of social inequities. Die Deutsche Schule 16, 153-162. https://doi.org/10.31244/9783830992318.09

Hayat, O., Loubna, K., Mohamed, B., Nour, E., Hamada, I., Noureddine, B., Amine, E., \& Mohamed, B. (2020). Pathogenesis of coronavirus disease 2019 (COVID-19): evaluation and prevention, Journal of Immunology Research, 2020, 1-7. https://doi.org/10.1155/2020/1357983

Jurková, V., Žežula, I., \& Klein, D. (2020). Testing on the growth curve model with intraclass correlation structure. Statistics, 54(5), 1124-1146. https://doi.org/10.1080/02331888.2020.1811983

König, J., Jäger, D., \& Glutsch, N. (2020). Adapting to online teaching during COVID-19 school closure: teacher education and teacher competence effects among early career teachers in Germany. European Journal of Teacher Education, 43(4), 608622. https://doi.org/10.1080/02619768.2020.1809650

Mellinger, Ch., \& Hanson, T. (2016). Descriptive statistics. Routledge.

Mendoza, D. Nieto, Z., \& Vergel M. (2019). Technology and mathematics as a cognitive component. Journal of Physics: Conference Series, 1414, 012007. https://doi.org/10.1088/1742-6596/1414/1/012007

Mirbabaie, M., Bunker, D., Stieglitz, S., Marx, J., \& Ehnis, C. (2020). social media in times of crisis: learning from hurricane harvey for the response to the 2019 coronavirus disease pandemic. Journal of Information Technology, 35(3), 195-213. https://doi.org/10.1177/0268396220929258

Olasile, B., \& Soykan, E. (2020). Covid-19 pandemic and online learning: challenges and opportunities, interactive learning environments. Interactive Learning Environments, 28, 1-13. https://doi.org/10.1080/10494820.2020.1813180
PROBLEMS

OF EDUCATION

IN THE $21^{\text {st }}$ CENTURY

Vol. 79, No. 2, 2021 
Magda Francisca CEJAS MARTÍNEZ, Mercedes NAVARRO CEJAS, Gina Silvana VENEGAS ALVAREZ, Carlos Enrique PROAÑO RODRÍGUEZ, Derling Jose MENDOZA VELAZCO. Student perceptions of Ecuadorian virtual platforms during the Covid-19 pandemic

PROBLEMS

OF EDUCATION

IN THE $21^{\text {st }}$ CENTURY Vol. 79, No. 2, 2021

252

Pari, A., Mendoza, D., \& Auccahuallpa, R. (2020). GeoGebra as a technological tool in the process of teaching and learning geometry. Communications in Computer and Information Science, 1307, 1-14. https://doi.org/10.1007/978-3-030-62833-8_20

Primicias, (2020). Ecuador declares health emergency by spreading coronavirus. https://www.primicias. ec/noticias/sociedad/ecuador-declara-emergencia-sanitaria-por-propagacion-del-coronavirus/

Rapanta, C., Botturi, L., Goodyear, P., Guàrdia, L., \& Koole, M. (2020). Online college education during and after the Covid-19 crisis: reorientation of teaching presence and learning activity. Postdigital Science and Education, 2, 923-945. https://doi.org/10.1007/s42438-020-00155-y

Sindiani, A., Obeidat, N., Alshdaifat, E., Elsalem, L., Alwani, M., Rawashdeh, H., Fares, A., Alalawne, T., \& Tawalbeh, L. (2020). Distance education during the COVID-19 outbreak: A cross-sectional study among medical students in North of Jordan. Annals of Medicine and Surgery, 59, 186-194.

Singhal, T. (2020). Coronavirus review disease-2019 (COVID-19). Indian Journal of Pediatrics, 87(4), 281-286.

Sintema, E. (2020). Effect of COVID-19 on grade 12 student performance: implications for STEM education. Eurasia Journal of Mathematics, Science and Technology Education, 16(7), 1-6. https://www.ejmste.com/download/effect-of-covid-19-on-the-performance-of-grade-12-studentsimplications-for-stem-education-7893.pdf

Sun, L., Tang, Y., \& Zuo, W. (2020). Coronavirus boosts online education. Nature Materials, 19, 687. https://doi.org/10.1038/s41563-020-0678-8

Wahab, A. (2020). Online and remote learning in higher education institutes: a necessity in light of COVID-19 pandemic. Higher Education Studies, 10(3), 16-25. https://doi.org/10.5539/hes.v10n3p16

Waller, R., Hodge, S., Holford, J., Milana, M., \& Webb, S. (2020). Lifelong education, social inequality and the COVID-19 health pandemic. International Journal of Lifelong Education, 39(3), 243246. https://doi.org/10.1080/02601370.2020.1790267

Zhang, L., Ray, H., Priestley, J., \& Tan, S. (2020). A descriptive study of variable discretization and costsensitive logistic regression on imbalanced credit data. Journal of Applied Statistics, 47(3), 568581. https://doi.org/10.1080/02664763.2019.1643829

Zhao, W., Zhang, F., Wang, X., Li, R., \& Lian, H. (2019). Primary variable coefficient estimator for highdimension models. Statistics, 53(6), 1234-1250. https://doi.org/10.1080/02331888.2019.1663521

Zhou, L., Wu, S., Zhou, M., \& Li, F. (2020). School's out, but class on, the largest online education in the world today: Taking china's practical exploration during the COVID-19 epidemical prevention and control as a example. Best Evidence in Chinese Education Journal, 4(2), 501-519. 


\section{Appendix A. Questionnaire applied to university students for data collection.}

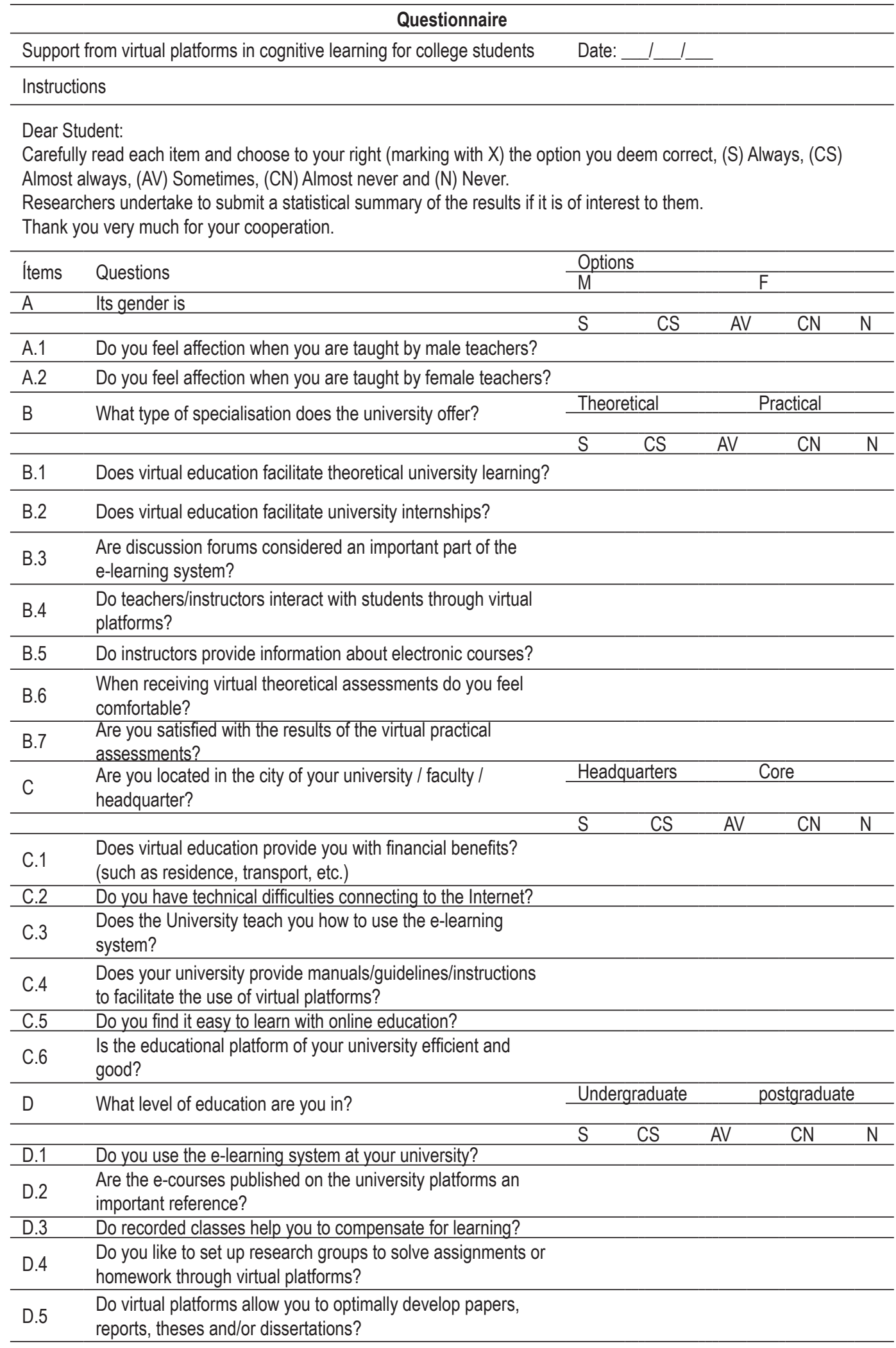


Magda Francisca CEJAS MARTÍNEZ, Mercedes NAVARRO CEJAS, Gina Silvana VENEGAS ALVAREZ, Carlos Enrique PROAÑO RODRÍGUEZ, Derling Jose MENDOZA VELAZCO. Student perceptions of Ecuadorian virtual platforms during the Covid-19 pandemic

PROBLEMS

OF EDUCATION

IN THE $21^{\text {st }}$ CENTURY

Vol. 79 , No. 2,2021
Received: February 18, 2021

Accepted: April 04, 2021

Cite as: Cejas Martinez, M. F., Navarro Cejas, M., Venegas Alvarez, G. S., Proano Rodriguez, C. E., \& Mendoza Velazco, D. J. (2021). Student perceptions of Ecuadorian virtual platforms during the Covid-19 pandemic. Problems of Education in the $21^{\text {st }}$ Century, 79(2), 241-254. https://doi.org/10.33225/pec/21.79.241

\begin{tabular}{|c|c|}
\hline Magda Francisca Cejas Martínez & $\begin{array}{l}\text { PhD in Economics and Research, Professor, National University } \\
\text { the Chimborazo UNACH and University of the Armed Forces ESF } \\
\text { Riobamba, Ecuador. } \\
\text { E-mail: magda.cejas@unach.edu.ec } \\
\text { ORCID: https://orcid.org/0000-0002-0618-3608 }\end{array}$ \\
\hline Cejas Mercedes Navarro & $\begin{array}{l}\text { PhD in research, professor at the Technical University of Manabi, } \\
\text { Ecuador. } \\
\text { E-mail: mechyn4@gmail.com } \\
\text { ORCID: https://orcid.org/0000-0003-4377-7250 }\end{array}$ \\
\hline Gina Silvana Venegas Alvarez & $\begin{array}{l}\text { Research Professor at Cotopaxi Technical University. Ecuador. } \\
\text { Email: gina.venegas@utc.edu.ec } \\
\text { ORCID: https://orcid.org/0000-0001-8356-6162 }\end{array}$ \\
\hline $\begin{array}{l}\text { Carlos Enrique Proaño } \\
\text { Rodríguez }\end{array}$ & $\begin{array}{l}\text { Research Professor at the University of the ESPE Armed Forces. } \\
\text { Director of the Department of Languages. ESPE-L. Ecuador. } \\
\text { Email: ceproanio@espe.edu.ec } \\
\text { ORCID: https://orcid.org/0000-0002-9709-4634 }\end{array}$ \\
\hline $\begin{array}{l}\text { Velazco Derling Jose Mendoza } \\
\text { (Corresponding author) }\end{array}$ & $\begin{array}{l}\text { Teacher and researcher, Dr. in education and research. National } \\
\text { University of Education and UTE University. Quito, Ecuador. } \\
\text { E-mail: derling969@gmail.com } \\
\text { ORCID: http://orcid.org/0000-0001-8275-3687 }\end{array}$ \\
\hline
\end{tabular}

